"TURY'ZM" 1991, z. 2

Janusz Sewerniak

\title{
GEOGRAFIA TURYZMU A PLANOWANIE PRZESTRZENNE W POLSCE W LATACH DZIEWIĘCDZIESIĄTYCH
}

\section{LA GEOGRAPHIE DU TOURISME ET LA PLANIFICATION SPATIALE EN POLOGNE \\ DANS LES ANNEES QUATRE-VINGT-DIX}

GEOGRAPHY OF TOURISM AND SPATIAL PLANNING IN POLAND IN THE 90'S

Dziedziną zastosowań rezultatów poznania geografii turyzmu w zakresie zagospodarowania turystycznego jest planowanie przestrzenne. Głównym zadaniem geografii turyzmu wobec planowania przestrzennego jest określenie zbioru reguł umożliwiających racjonalne sterowanie ruchem turystycznym przez odpowiednie zagospodarowanie turystyczne. Co należy uczynić aby geografia turyzmu w latach dziewięćdziesiątych była bardziej niż dotąd użyteczna dla praktyki planistycznej?

$\mathrm{Na}$ podstawie dotychczasowych doświadczeń wydaje się, że celowe jest wyodrębnienie nurtu, który umownie można nazwać jako z a s tosowania geografii turyzmu w planowaniu przestrzennym. W tych ramach powinien być dokonany przegląd, a następnie synteza dotychczasowego stanu badań geografii turyzmu pod kątem wykorzystania wniosków w planowaniu przestrzennym. W nawiązaniu do stref krajobrazowych Polski dotyczy to opracowania: 1) metodyki zbierania informacji oraz 2) strategii rozwiązywania problemów planistycznych zagospodarowania turystycznego.

Przegląd oraz synteza metod zbierania informacji dotyczących problematyki zagospodarowania turystycznego $\mathrm{w}$ regionach $\mathrm{i}$ miejscowościach turystycznych winny zmierzać do opracowania podstaw $f i z j o-$ grafii turystycznej. Jej najogólniej pojmowanym celem powinna być analiza i ocena cech przestrzeni geograficznej dla osadnictwa turystycznego. Obejmuje to zespół informacji o: 1) stanie środowi- 
ska geograficznego dla turystyki oraz 2) przewidywanych skutkach zagospodarowania i użytkowania turystycznego. W szczególności należą tu informacje dotyczące np: kolizji funkcji, przewidywanych zmian środowiska przyrodniczego, zasad kształtowania krajobrazu, ekspozycji dominant urbanistycznych i krajobrazowych, natężenia hałasu, spalin itp.

Dla strategii rozwiązywania problemów planistycznych zagospodarowania turystycznego kluczowe znaczenie ma opracowanie wskaźnikó użytkowania turystycznego, co dotyczy chłonności, pojemności i przepustowości turystycznej. Przy konstrukcji tych wskaźników poza uwarunkowaniami środowiska przyrodniczego i możliwościami recepcji bazy turystycznej większą uwagę należy zwrócić na czynniki związane z percepcją przestrzeni turystycznej przez uczestników poszczególnych form ruchu turystycznego. W akcentowanym tu podejściu humanistyeznym należy jednak dążyć do ostatecznych ujęć normatywnych, co związane jest $\mathrm{z}$ oczekiwaniami praktyki planistycznej.

W latach dziewięćdziesiątych wobec: 1) zmian systemowych planowania przestrzennego wyrażających się przede wszystkim odejściem od planowania centralnego oraz 2) spodziewanej aktywizacji samorządów terytorialnych na rzecz rozwoju turystyki można założyć wzrost znaczenia planowania przestrzennego zagospodarowania turystycznego na szczeblu regionalnym, a zwłaszcza lokalnym. W tej sytuacji ważną rolę powinno spełnić opracowanie zarówno podstaw fizjografii turystycznej, jak i wskaźników uźytkowania turystycznego dla stref krajobrazowych Polski. Może to stanowić jednocześnie jedną ze wskazówek co do wyboru kierunków badawczych geografii turyzmu.

Dr Janusz Sewerniak Instytut Turystyki

Wpłynęło:

Oddział w Toruniu 31 stycznia 1991 r.

uI. M. Konopnickiej 27

87-100 Toruń 